\title{
Implications of Seed Policies for On-Farm Agro-Biodiversity in Ethiopia and Uganda
}

\author{
Gloria Atieno Otieno ${ }^{1}$, Travis W. Reynolds ${ }^{2}$, Altinay Karasapan ${ }^{3} \&$ Isabel Lopez Noriega $^{4}$ \\ ${ }^{1}$ Bioversity International, Regional Office of Kampala, Uganda \\ ${ }^{2}$ Colby College, Environmental Studies Program, United States \\ ${ }^{3}$ National Sustainable Agriculture Coalition, United States \\ ${ }^{4}$ Bioversity International office in Rome, Italy \\ Correspondence: Gloria Atieno Otieno, Bioversity International, Regional Office of Kampala, Uganda. E-mail: \\ g.otieno@cgiar.org
}

\author{
Received: May 19, 2017 Accepted: July 2, 2017 Online Published: August 3, 2017 \\ doi:10.5539/sar.v6n4p12 URL: https://doi.org/10.5539/sar.v6n4p12
}

\begin{abstract}
Across East Africa, national seed policies and commercial seed enterprises have focused on increasing farmers' access to modern seed varieties. These new varieties are developed and delivered to farmers via the formal seed system, which is comprised of government and private sector seed breeders, processors, and vendors. However, the formal seed system only provides a small share $(<20 \%)$ of smallholders' seed in the region. Most farmers source seed from informal seed systems, including own-saved seed, exchanges with neighbors, and local seed markets. At the local level, informal seed systems are preferred by farmers because of proximity and local varietal preferences (e.g., crop variety tastes and suitability for local environmental conditions). At the national and regional levels, the conservation and use of local crop varieties through informal systems has also provided a wealth of crop genetic diversity increasingly recognized as critical for climate change adaptation. To evaluate how policies in East Africa impact seed systems we systematically code 117 provisions in 21 national seed policies in Ethiopia $(n=11)$ and Uganda $(n=10)$, highlighting the implications of current and proposed policies for the availability and accessibility of: (i) improved seed; (ii) quality-controlled seed; and (iii) genetically diverse local seed in both the formal and informal seed systems in each country.
\end{abstract}

Keywords: seed policies, agro-biodiversity, food security, Ethiopia, Uganda, genetic diversity, formal and informal seed systems

\section{Introduction}

In Africa, the agricultural sector dominates rural livelihoods and the economy. The overwhelming majority of rural residents are smallholder farmers (Joughin, 2014; Thijssen et al., 2008); this is also true for Ethiopia and Uganda. Without access to alternative sources of food or income, smallholders are highly vulnerable to fluctuations in weather patterns (Di Falco et al., 2010), to changes in government support (World Bank, 2015), and to shifts in both local and international markets (Joughin, 2014; Alemu, 2010). These contextual variables are directly linked to food security at the household and regional levels (Kristjanson et al., 2012). Food insecurity continues to be a pervasive problem in Sub Saharan Africa, especially in smallholder-based food systems (Bangawyo-Skeete, 2012). These problems are exacerbated by other factors impacting food access and production, including a growing population, spikes in food prices, declining soil fertility, and climate change (Kristjanson et al., 2012; Barungi et al., 2011; Holden et al., 2004).

One way government policies can influence smallholder food production is through strengthening seed systems (Vernooy, 2017; Mahop, 2015; de Boef et al., 2010; Bezabih, 2008; Tripp \& Louwaars, 1997) and improving the overall availability and accessibility of high quality seeds (Barungi et al., 2015; Lukwago, 2010). A growing body of scholarship and field research now shows that access to high quality and diverse planting materials is associated with reductions in pests and disease, increased resilience to drought and other crop stressors (Bangwayo-Skeete et al., 2012), and ultimately increased food production, food security, and farmer livelihood stability (Joughin, 2014; Louwaars et. al, 2013; Di Falco et al., 2010).

The goal of increasing farmer access to "quality seed" has rapidly gained prominence in national and 
international policy debates (CTA, 2014), and has become a central focus of international aid programs targeting agricultural productivity (AGRA, 2013; Sperling et al., 2003). However, the question of what constitutes "quality seed" in seed systems is complex; leading to disagreements over the definition of goals and associated metrics for measuring success in policies targeting food systems (Reardon \& Timmer, 2012). Most modern seed policies embrace a concept of quality that relies on three pillars:

1) The Value for Cultivation and Use of the Variety: A variety has a sufficient value for cultivation and use when it shows a significant improvement over existing cultivars in terms of the harvest, or the products that are obtained. Usually, the first measure of this value is productivity (Evenson \& Gollin, 2003; Alston et al., 2000), followed by resistance to pests and diseases and other characteristics of commercial importance.

2) The Uniformity and Homogeneity of the Variety: A variety is considered uniform and homogenous when all plants of that variety are uniform in their essential characteristics and highly stable after repeated multiplication (Bishaw et al., 2012).

3) The Health of the Seed: Seed health is measured in terms of phytosanitary standards including high germination percentage, being free from diseases, and storage properties with a proper moisture content and weight (Bishaw et al., 2013).

A number of critics have argued that high yield, uniform and homogeneous, and healthy/sanitary varieties do not always meet farmers' needs and consumer preferences. In addition, an emphasis on "quality seed" can lead to the decrease of the genetic richness of local crops, threatening the in situ conservation of genetic diversity necessary for future investments in cultivar improvement (Smale, 2006). The recent development of an emphasis on quality seed has the potential to impact agricultural systems' present resilience (Tura et al., 2010; Di Falco et al., 2009) and poor communities' food security and livelihoods (Teklewold et al., 2013; Di Falco et al., 2010). It has also been argued that an emphasis on seed traits such as genetic purity, seed cleanliness and good germination performance undermines traditional seed suppliers' capacities to continue providing seed which meets farmers' other exigences of quality (African Centre for Biodiversity, 2016). Indeed, the definition of quality in the sense presented above is aligned with the work carried out by research organizations, seed enterprises and other institutions involved in the formal seed sector, but it may not provide enough space for more rudimentary and unespecialized seed systems, which rely on farmers as the main seed suppliers, and which still represent the majority of the seed produced in developing countries (McGuire \& Sperling, 2016; de Boef et al, 2010).

This research summarizes how current institutions and policies related to seed production and distribution in Ethiopia and Uganda influence the shaping of seed systems in these countries, and considers whether policies provide space for informal seed systems to continue to operate and evolve and for farmers to utilize local and traditional varieties together with improved ones. We start this paper in Section 1.1 with an overview of the seed sectors in both countries, paying attention to the role of informal seed systems and local and traditional varieties in agricultural production. Section 2 then describes our methods for systematically reviewing seed and seed related policies for Ethiopia and Uganda, analyzing the implications of policies for the availability and accessibility of improved, quality-controlled, and genetically diverse seed in the formal and informal seed systems in each country. Section 3 of the paper gives a summary of the findings and consisting of the expected impacts of the policies on informal and formal seed systems; and availability and accessibility of diverse seed in both formal and informal sectors. The fourth section discusses the policy implications of the findings for agro-biodiversity and food security and the final section, section 5, summarizes our conclusions and recommendations for policy.

\subsection{Formal and Informal Seed Systems in Agricultural Development}

Both Ethiopia and Uganda have long embraced the theory of agricultural development led industrialization, which has been a central pillar of national and international development policy in East African countries since the 1990s. Many East African countries share a common seed provision strategy whereby public agencies develop and distribute new seed varieties that are subject to a number of regulations involving many governmental agencies. Despite the considerable amount of research on how to strengthen national seed sectors, the international community remains divided on the best path. Some consider the regulatory environment in East Africa as unnecessarily stringent and too heavily limiting seed imports (Pelum, 2012). Others argue that liberalization of the seed sector has resulted in the multiplication of inefficient parastatal seed companies who often cannot provide the desired quality of seed at the necessary volume or price (Sperling \& McGuire, 2010). Several institutional and infrastructural barriers have led to a lack of clarity and enforcement of seed policies in the region (Ethiopian ATA, 2015; Barungi et al., 2014; Pelum Uganda, 2012), which has resulted in the rise of a counterfeit seed trade, which has in turn reduced trust and ultimately the use of improved quality seed from the 
formal seed sector promoted by state governments in both Ethiopia and Uganda (Joughin, 2014; Ngos, 2012). Despite the tremendous investment in the form of donor aid and the regional harmonization of seed policies, a large portion of farmers still lack access to sufficient quality seed.

Nowadays, formal and informal systems of seed production and supply exist in both countries. Informal sources include farmer-saved seeds, farmer-to-farmer seed exchange and farmer-managed seed production. For decades these informal sources have been the primary sources of new planting material for smallholders (Atilaw, 2010). Currently only about 20 percent of seed used across Africa is certified seed, with the remainder - some 60-80 percent of seed used by farmers - coming from informal sources and not subject to quality certification schemes (CTA, 2014). Published estimates suggest informal seed sources account for as much as $82 \%$ of seed used by Ugandan smallholders (Bocci et al., 2010); furthermore, a recent survey in Uganda found the three primary sources of bean seed (own seed, local market seed and seed from neighbors) to all be informal channels (Author survey, 2015). Studies in Ethiopia have revealed similarly high levels of reliance on informal seed channels: a 2010 ICRISAT study in the Southern Nations, Nationalities, and People's Region (SNNPR) found only 15.5\% of farmers sourced their seeds from the formal sector (i.e., seed companies and government), with the other $84.5 \%$ sourcing seeds from informal sources (i.e., grain markets and social networks) (Katungi et al., 2010).

Informal seed sources play especially important roles during times of volatile weather, political conflict, or other unstable periods; in such contexts informal seed systems offer immediate and flexible access to needed farm inputs (Sisay et al., 2017; Sperling et al., 2009). However, informal seed systems may suffer from a lack of quality control mechanisms and cannot guarantee minimum quality standards (de Jonge, 2014; Gibson, 2013). This limitation is exacerbated in many parts of Sub-Saharan Africa where migration, aging rural populations, and the emergence of local food and seed markets where sellers and customers do not know each other are weakening the social connections that once allowed farmers to access reliable information about the quality of available seed (Coulibaly et al., 2014).

The formal seed system, in contrast, is comprised of established and formally recognized state and commercial institutions engaged in seed research, development, and distribution. This system is largely responsible for producing and diffusing modern varieties in the form of quality seed, ultimately with an aim to promote higher yields (Santos, 2007), increased incomes and subsequently, food security. Though small relative to informal seed systems, the formal seed sector in East Africa has grown rapidly in recent years with support from government and commercial investment in research, production, processing and marketing (PELUM, 2012). But in spite of this rapid growth and substantial government support, accessibility and cost remain deterrents to the participation of smallholdersin formal seed markets (de Jonge, 2014). Moreover, despite some government efforts to invest in a broad range of improved crops and varieties, much of the focus of the formal seed sector in the region remains on highly commercialized crops, such as maize (Barungi et al., 2014; CTA, 2014).

Table 1 summarizes the key characteristics and differences between the formal and informal seed sectors in East Africa, and provides statistics on the informal sector's overwhelming current scope in both Ethiopia and Uganda.

Table 1. Comparison of the formal and informal seed sectors in Ethiopia and Uganda

\begin{tabular}{|c|c|c|}
\hline Overview & $\begin{array}{l}\text { Formal Seed Sector } \\
\text { Organized on a commercial basis, regulated by government and } \\
\text { linked to research, production, processing and marketing. Of high } \\
\text { genetic purity and with standardized packaging and labeling }{ }^{1}\end{array}$ & $\begin{array}{l}\text { Informal Seed Sector } \\
\text { Farmers save own seeds to use from season to } \\
\text { season, farmers sell seeds to neighbors, farmer } \\
\text { groups grow seed and sell in local markets }\end{array}$ \\
\hline Seed source & $\begin{array}{l}\text { - Public seed enterprises, e.g., ESE } \\
\text { - Private seed companies } \\
\text { - Non governmental organizations working under development } \\
\text { projects }\end{array}$ & $\begin{array}{l}\text { - Own-saved seed } \\
\text { - Other farmers } \\
\text { - Community seed banks } \\
\text { - Local food markets }\end{array}$ \\
\hline Seed type & $\begin{array}{l}\text { - Improved, commercially bred or genetically modified varieties }{ }^{3} \\
\text { - Varieties tested for uniformity and stability standards, and then } \\
\text { released and registered in the national catalogues of commercial } \\
\text { varieties } \\
\text { - Seed quality is monitored and certified by an external agency }\end{array}$ & $\begin{array}{l}\text { - Some improved varieties adopted, multiplied } \\
\text { and exchanged by farmers across seasons } \\
\text { - Mainly local varieties, which are not registered } \\
\text { in the national catalogues of commercial varieties, } \\
\text { nor released } \\
\text { - Seed quality is not monitored and certified by an } \\
\text { external agency }\end{array}$ \\
\hline $\begin{array}{l}\text { Percentage of } \\
\text { Seed Supplied }\end{array}$ & $\begin{array}{l}\sim 10 \% \text { Ethiopia }^{4} \\
\sim 20 \% \text { Uganda }^{5-6}\end{array}$ & $\begin{array}{l}\sim 90 \% \text { in Ethiopia } \\
\sim 80 \% \text { in } \text { Uganda }^{5-6} \\
\sim 80\end{array}$ \\
\hline
\end{tabular}

In addition to these two seed systems, intermediate, hybrid systems have emerged and multiplied in the past 
decades. These hybrid systems combine elements of both formal and informal seed systems. For example, improved varieties developed by the formal sector are multiplied and distributed by farmer organizations. Non-governmental organizations provide support for the certification of farmer producer seed, according to the quality requirements imposed by national seed laws (Vernooy, 2017). Usually, these hybrid or intermediate systems are closer to the informal local systems than to the formal seed systems: they have a local coverage, are not supported by government initiatives and rely on farming communities' capacities, instead of on specialized seed industries.

Despite the prominence of the informal seed systems, much of the attention of national and international governments and for-profit actors has been focused on the development of a robust formal seed sector (Sperling \& McGuire, 2010; Ssebuliba, 2010). At the same time, governments and aid agencies in Sub-Saharan Africa have prioritized the development and dissemination of high-yielding varieties with resistance to biotic and abiotic stressors, intended for distribution via the formal seed system. However, there is evidence to suggest that these varieties do not always perform well, particularly in remote areas with extreme and variable environmental conditions and in the absence of agricultural inputs such as irrigation and fertilizers (Ben Hassen et al. 2017; Reimer and Fisher, 2016; Singh, Kumar and Pal, 2016; Ceccarelli, 1996). Local and traditional varieties may be better adapted to existing environmental and socioeconomic conditions and hence more able to provide stable and consistent yields over the years (Di Falco et al., 2010; Lipper et al., 2005). The lack of uniformity and stability of these varieties may actually be of value in those agro-ecological environments where climate conditions, pests and diseases present quick and dramatic fluctuations. Genetic richness across different local varieties and within populations of the same variety allows the crop to more quickly and easily evolve and adapt to changing conditions as compared to the less genetically diverse modern varieties (Jarvis et al., 2016; Vigouroux et al., 2011; Bellon, 2004). A number of experts have pointed out that the exclusive attention to and promotion of modern varieties by governments and international initiatives may have negative effects on countries' agricultural production (de Boef et al., 2010). In the short term, a shift towards decreasing genetic diversity in smallholder farm communities may reduce farmers' capacity to adapt to environmental stressors (Lipper et al., 2010; Di Falco et al., 2010; Lipper et al., 2005). In the long term the loss of crop genetic diversity has implications for state and private sector breeding efforts - as Kahane et al. (2013) note, "all too often, such valuable genetic resources can be lost before they can be fully [developed] and used [by the general local populace]" (p. 672).

The important role played by the informal seed sector in rural communities in Sub-Saharan Africa has been increasingly recognized (Coomes et al., 2015; Joughin, 2014; Alemu, 2010; de Boef \& Bishaw, 2008; Engels et al., 2008), as well as the value of traditional, genetically diverse local varieties in low input farming systems. However, the extent to which public policies and initiatives in Ethiopia and Uganda pay attention to these two key elements of seed systems is still not clear. Furthermore, the actual or potential impacts of current policies on the informal seed sector and on the conservation and use of local varieties has not been properly analyzed and their effects are still poorly understood.

\section{Methods}

The research was conducted in Ethiopia and Uganda. The two countries are located in East Africa and face similar agricultural challenges. Both countries' food systems are characterized by mixed farming systems consisting of both animal and crop production with the majority of the agricultural sector consisting of smallholder farmers who make their living off of less than two hectares of land. Agriculture is commonly subsistence, low input-low output, and rain fed. Seed systems in both countries are predominantly informal with over 80 percent of seed coming from farm saved seed (Ngos, 2012; Atilaw, 2010; MAAIF, 2010). Both countries host important diversity for different crops, including beans, pearl millet, and cassava in Uganda and wheat, barley, and teff in Ethiopia. Although both countries have many similarities, they have different seed sector approaches, for instance Ethiopia's seed sector is predominantly government-controlled and public sector-oriented (Lipper et al., 2005) while Uganda's seed sector is more liberalized and private sector-oriented (Otieno \& Reynolds, 2015); which allows for comparison of policy approaches and seed system impacts.

This research began with a systematic literature review of peer reviewed journal articles and government reports providing information on the seed policy frameworks in Ethiopia and Uganda, as well as evidence on the past and present impacts of seed policies on the quality and genetic diversity of seeds used by farmers in the two countries. This review resulted in the identification of 21 national policies with substantial implications for seed systems in Ethiopia $(n=11)$ and Uganda $(n=10)$. Based on literature, we also identified criteria by which seed policies might be evaluated in terms of their implications for the availability and accessibility of improved and genetically diverse seed in the formal and informal seed systems in each country (Table 2). We distilled the 21 
national policy documents from Ethiopia and Uganda into 117 discrete seed policy provisions (with a provision defined as a unique declaration of a goal or allocation of resources to seed systems), and coded each provision in terms of: (i) how seed policies might impact the ultimate availability and accessibility of different varieties through different seed systems (formal and informal); and (iii) how seed policies might more directly impact availability of modern improved varieties, quality-controlled varieties, and genetically diverse farmers' landrace varieties.

Policy provisions were independently evaluated by two trained enumerators and assigned a score ranging from -2 to +2 for the predicted impact of the policy provision on availability and accessibility of each different type of seed (improved seed, quality seed, and genetically diverse landrace seed) in each seed system (formal and informal). A description of the coding scheme is provided in Table 2. In general terms -2 represents a direct constraint on availability (e.g., bans or limitations on imports) and accessibility (e.g., increasing the price of seed); -1 represents more indirect limits to availability and access (e.g., through increasing transaction costs associated with obtaining a given seed type); 0 represents that a policy has no measurable impact on availability or access; +1 represents an indirect support to availability and access of seed (i.e., the provision uses a general language like "support" or "encourage"); and +2 represents direct financial and/or institutional support for increasing the availability or accessibility of seed (including increasing imports, committing funding to research and development, and subsidies for the purchase of seed).

Table 2. Summary of seed policy coding criteria

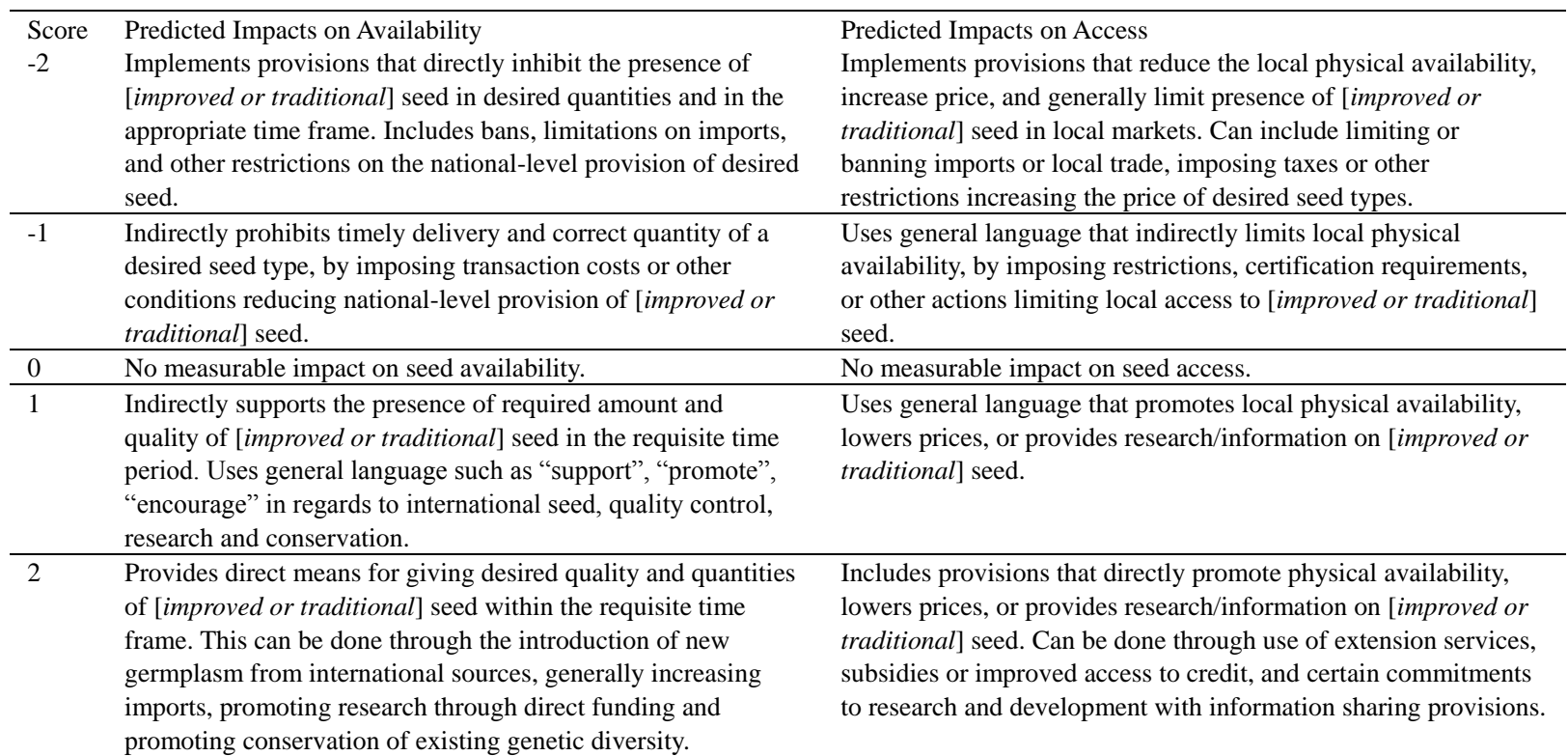

Source: Authors' compilations

We further applied this coding scheme to two major draft policies - the Ethiopian National Seed System Development Strategy (NSSDS) and the Ugandan Draft National Seed Policy (DNSP) - in the same manner as the currently enacted policies to consider the potential impacts these policies could have if enacted. The lists of coded policies and their abbreviations is provided in Figure 1. 


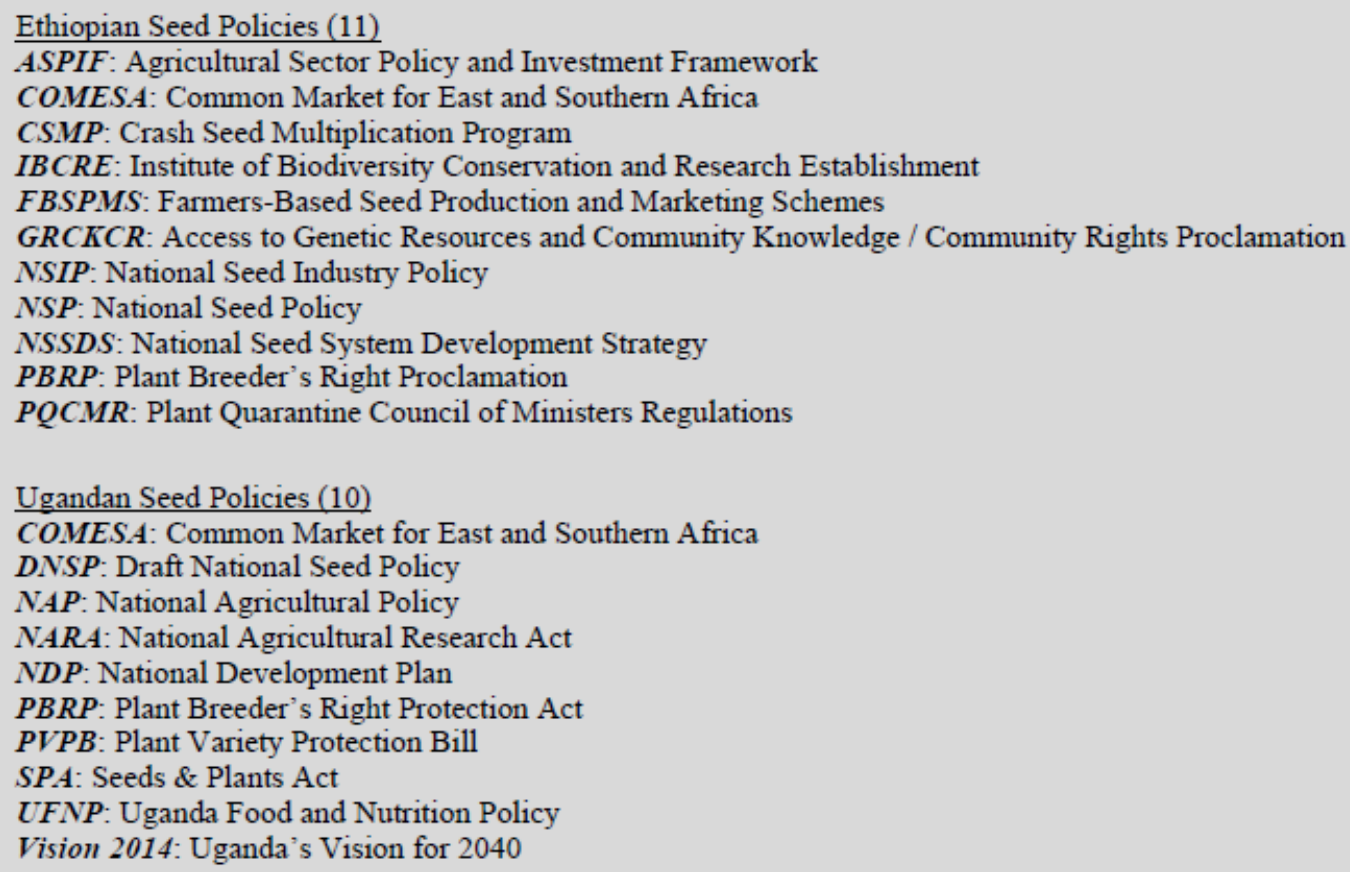

Figure 1. Names and abbreviations of major seed policies in Ethiopia and Uganda

\section{Results}

\subsection{Expected Policy Impacts on Formal and Informal Seed Systems}

In line with assumptions made in the literature (Muny \& de Jonge, 2015; CTA, 2014; Louwaars, 2007), we find that policy provisions are expected to have a much larger positive impact on the formal seed sector than on the informal sector in both Ethiopia and Uganda. Furthermore, negative impacts on availability and accessibility of seed are expected to be greater in the informal seed sector, with the possibility of negative impacts on both sectors. But while only $16 \%$ of coded provisions appear to have negative implications for the formal seed sector of Ethiopia, and $18 \%$ for the formal seed sector in Uganda, in comparison, 25\% of provisions appear to have negative impacts on the informal seed sector in Ethiopia and 39\% in Uganda. That said, in both countries we found that on net, more provisions could potentially have positive effects in both formal and informal seed systems (because they broadly support availability of, and access to, seed) (Figure 2).

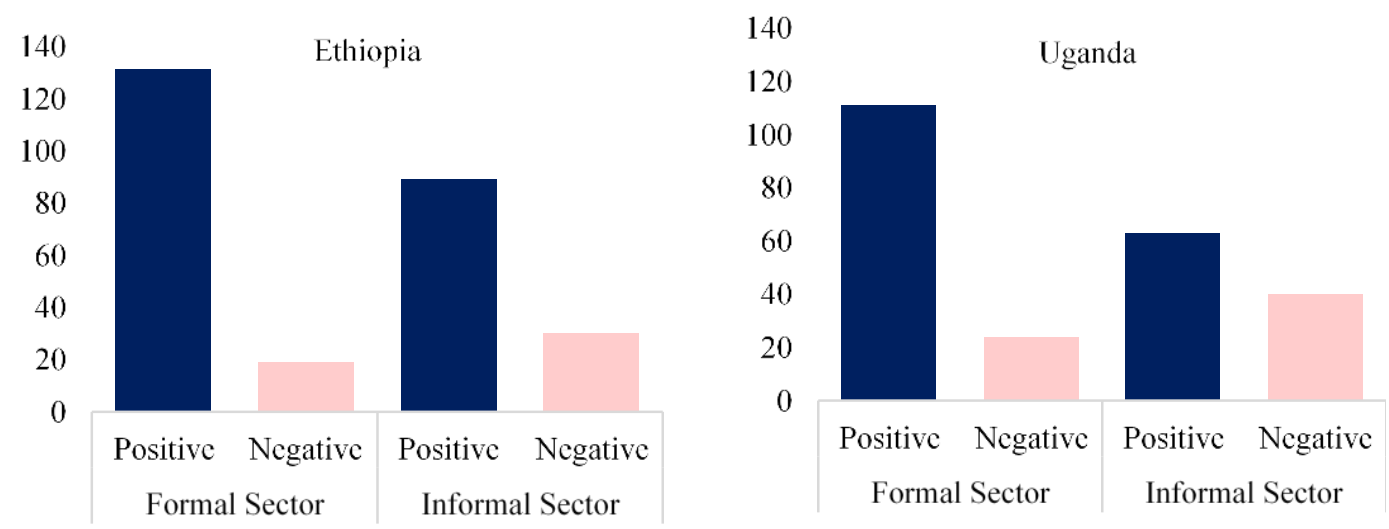

Figure 2. Count of relevant policy provision expected impacts as they relate to the formal and informal seed sectors in Ethiopia and Uganda 


\subsection{Availability and Accessibility of Improved and Traditional Varieties}

Consistent with expectations, in both countries there is a clear policy focus on improving the availability and accessibility of improved varieties. Figure 3 summarizes the expected effects of relevant provisions of seed and other agricultural policies on the availability and accessibility of the three categories of seed (improved variety seed, quality seed, and genetically diverse local seed) in the formal seed sector in Ethiopia. There is a relatively heightened policy focus on improving the availability and accessibility of improved seed and quality seed in this sector: improved and quality seed appear to have similar levels of positive policy provisions, with a range of about +40 to +45 in terms of effects based on the coding scheme scale. The largest predicted impacts are attributed to overarching policies such as the National Seed Sector Development Strategy (NSSDS), the Common Market for Eastern and Southern Africa (COMESA) and the National Seed Industry Policy (NSIP). Improved and quality seed also have few policies that negatively affect them: only the Plant Quarantine Council of Ministers Regulation (PQCMR) and the Plant Breeders' Right Proclamation (PBRP) have any negative expected effects (i.e., less than zero, making it more difficult or costly to obtain seed) on the availability and accessibility of improved and quality-controlled seeds in the formal seed system in Ethiopia - and the PQCMR's potential negative impacts on these seed types are more than offset by strong positive impacts on improved and quality seed availability and access through policy supports helping formal sector seed producers comply with standards and manage costs. In contrast, the availability and accessibility of genetically diverse landrace varieties are expected to be seriously limited by the provisions of the COMESA Seed Harmonization policies and the Crash Seed Multiplication Program (CSMP), both of which impose additional restrictions or costs on the formal seed trade which may represent barriers to farmers' use of genetically diverse landraces. Ultimately the possible negative effects of policies on the availability and accessibility of improved varieties in the formal seed sector are expected to be lower in Ethiopia than the expected negative effects on genetically diverse varieties.

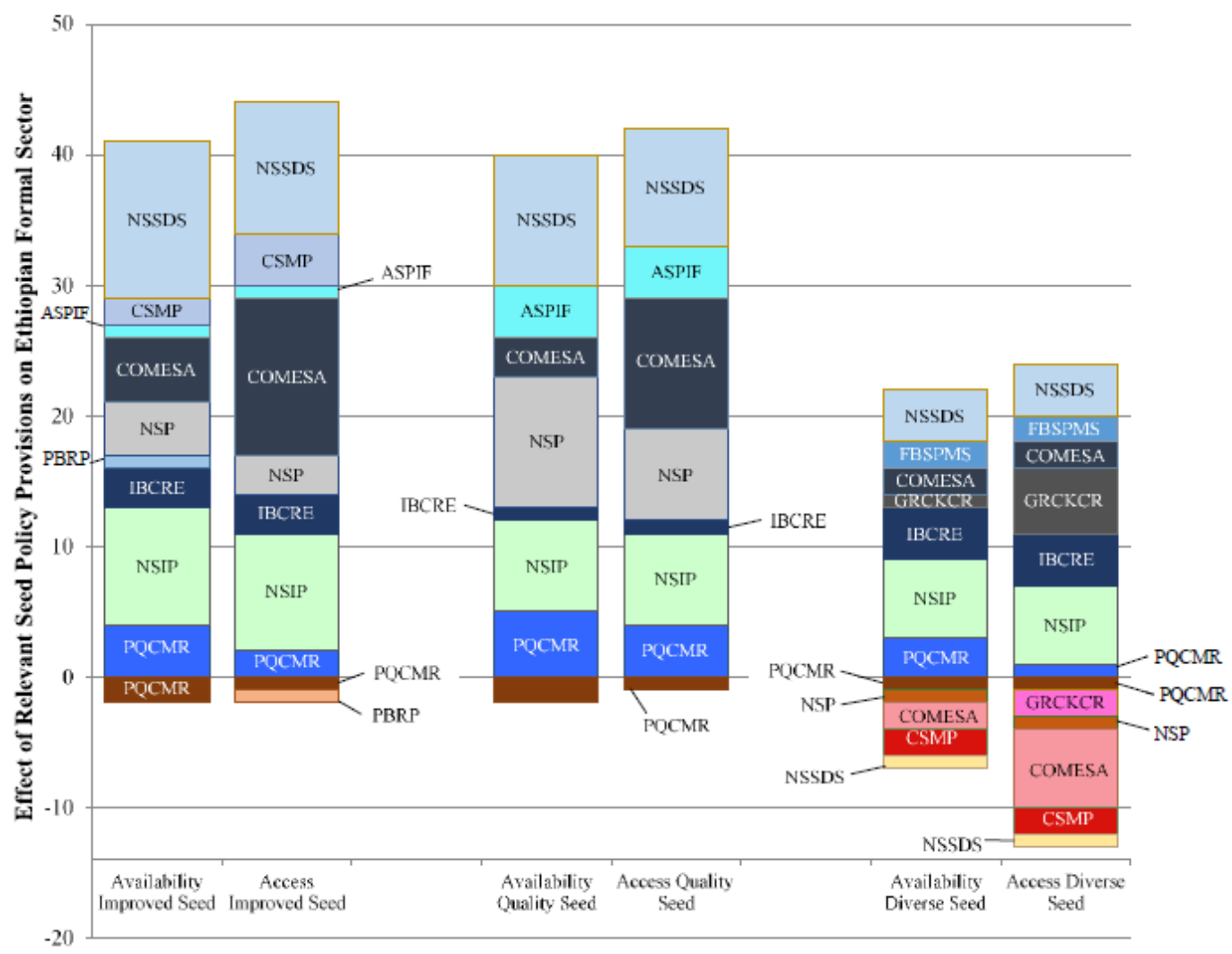

Figure 3. Ethiopia: predicted positive (above 0 ) and negative (below 0 ) effects of policy provisions in the availability (first column) and accessibility (second column) of improved varieties (on the left) and traditional varieties (on the right) in the formal seed sector

In the informal sector in Ethiopia, policies such as the NSSDS, but also COMESA and PBRP, work to engage the informal sector in promoting the utilization of improved and quality seed varieties. Only a few negative policy provisions were identified which could impact improved and quality seed in the informal sector, mostly owing to 
marketing restrictions introduced under the Plant Quarantine Council of Ministers Regulation (PQCMR). Moreover, unlike in the formal sector, there are some policies with the potential to enhance the availability and accessibility of genetic diversity in the informal seed sector in Ethiopia: the NSIP, the Institute for Biodiversity Conservation Research (IBCRE), and the draft NSSDS all explicitly aim to increase genetically diverse seed in the informal sector. There are also relatively high positive implications for genetically diverse seed (or landraces) in Ethiopian policy provisions attributed to the institution of the Access to Genetic Resources Community Knowledge and Community Rights (GRCKCR) policy, and the draft National Seed System Development Strategy (NSSDS). However, there are also many policy provisions with negative impacts on genetic diversity in this sector, many relating to COMESA and the Agricultural Sector Policy and Investment Framework (ASPIF).

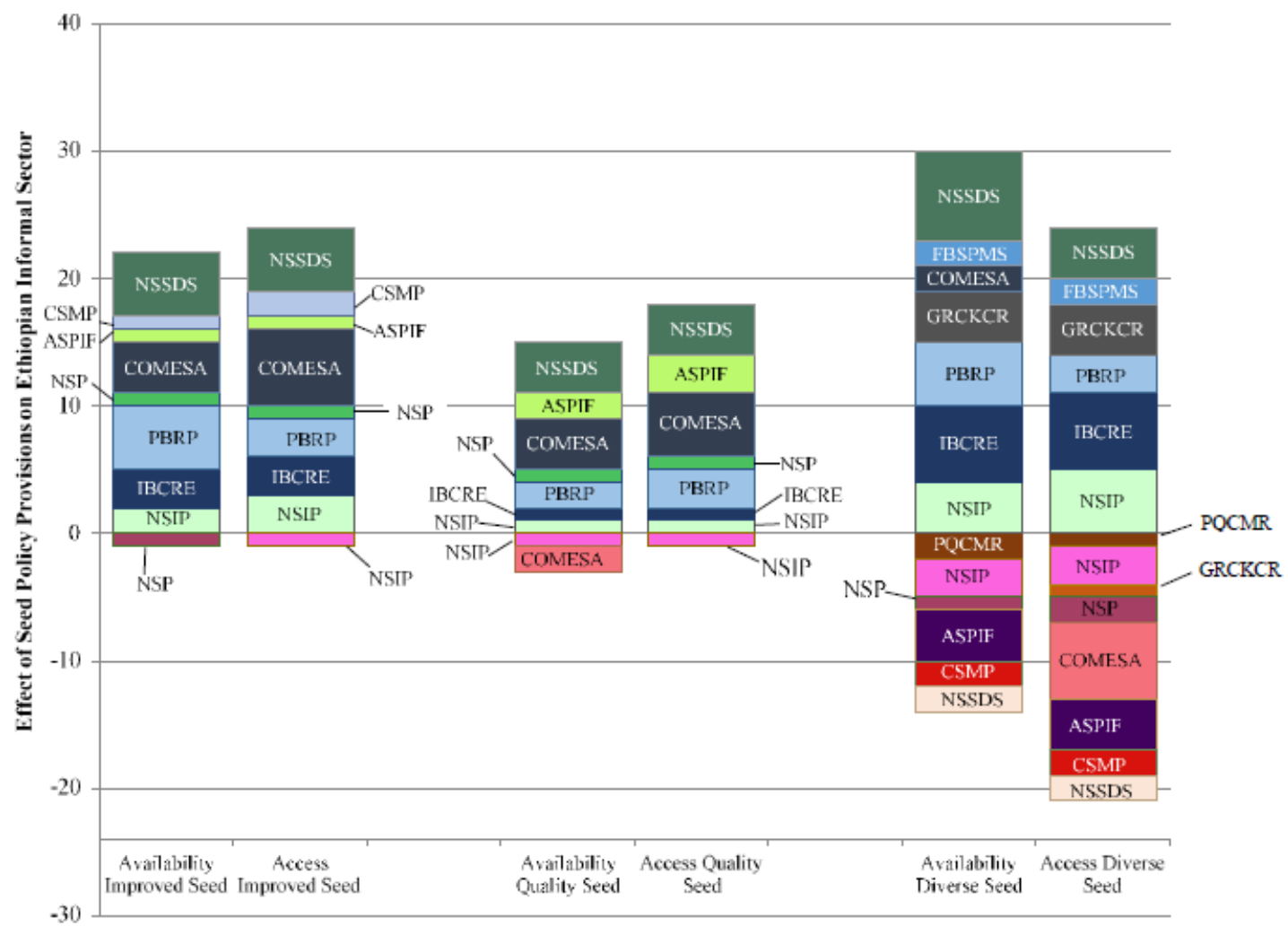

Figure 4. Ethiopia: predicted effect of seed policy provisions affecting improved, quality and genetically diverse seed in the informal sector (availability \& accessibility)

Overall, however, we observe many more positive implications for genetically diverse seed in Ethiopian seed policies - including those targeting the formal and informal seed sectors - as compared to Ugandan policies (Figure $5 \& 6$ ). Figure 5 highlights the predicted impacts of seed policies on the availability and accessibility of improved, quality and genetically diverse seed in Uganda's formal seed sector. Overall, the policies combined are predicted to have a net positive effect for each seed type. Quality and improved seed are expected to be the most positively impacted for both accessibility and availability. Genetically diverse (landrace) seed is expected to have the lowest net positive effect. In fact, access to landrace seed is predicted to have the highest net negative impacts and lowest overall net positive impacts. For example COMESA is predicted to have a strong, positive impact on the access to improved and quality seed through the formal sector (through enhancements to trans-boundary seed trade) yet a negative impact on access to genetically diverse landrace varieties (owing to stricter local seed exchange rules). The Plant Variety Protection Bill (PVPB) was the only coded policy to show a possible negative impact for the access and availability of each seed type (increasing legal protections for seed producers and hence, in the short term, decreasing farmer access to seed). The more overarching policies such as COMESA, the Seeds and Plants Act (SPA) and the National Agriculture Research Act (NARA) prioritize improving the access and availability of improved and quality seed above genetically diverse landrace seed in the formal sector. 


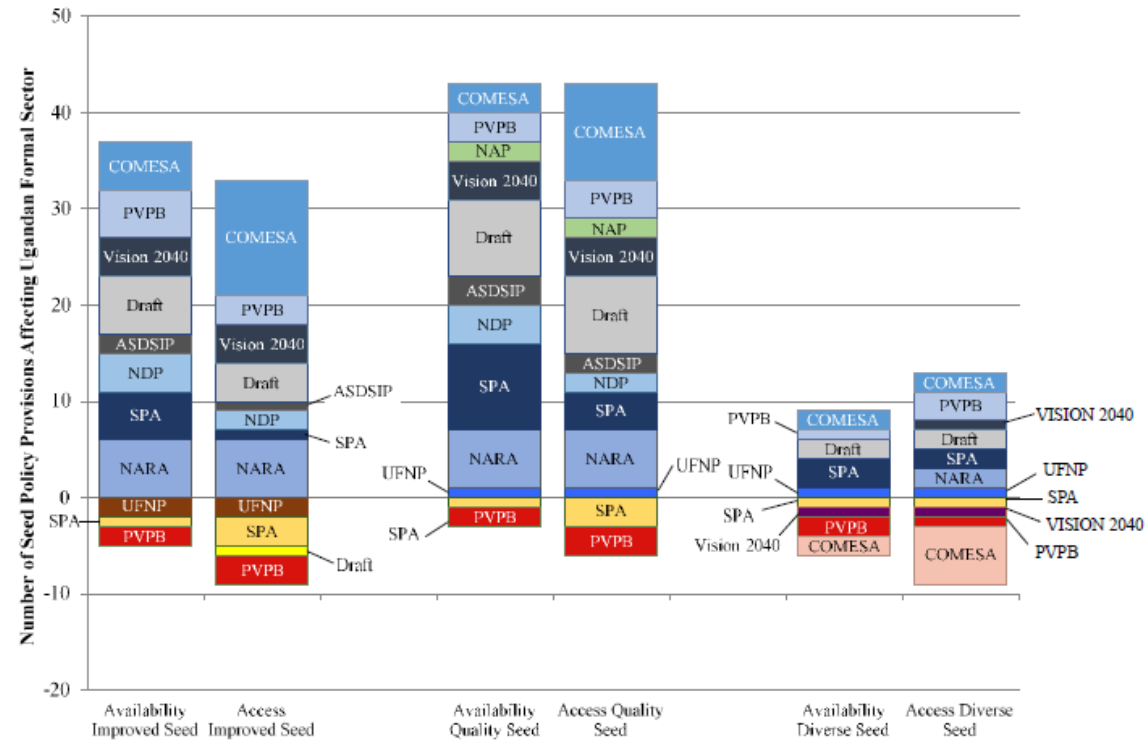

Figure 5. Uganda: net effect of seed policy provisions affecting improved, quality and genetically diverse seed in the formal sector (availability \& accessibility).

Figure 6 shows the expected effect of seed policies on the availability and accessibility of improved, certified quality and genetically diverse seed in Uganda's informal seed systems. As an overall trend, Ugandan policies appear to affect the informal sector significantly less than Ethiopian policies (note the y-axis scales). To begin, the Draft Seed National Policy (Draft), COMESA, the National Agriculture Research Act (NARA) and Vision 2040 seem to play the largest roles in positively affecting availability and access to all seeds, especially for improved and certified quality varieties. The Seeds and Plants Act (SPA) and the Biotechnology and Bio-safety Bill (BTBSB) appear to have modest negative implications for availability and accessibility of improved and certified quality seeds, both through imposing additional phytosanitary and approval requirements predicted to increase seed costs. On the other hand, availability and accessibility of genetically diverse landraces only see modest support from policies including the National Agriculture Research Act (NARA), the Draft Seed National Policy, and COMESA, while the SPA, the National Development Policy (NDP), and COMESA all have significantly negative predicted impacts on landrace availability and use.

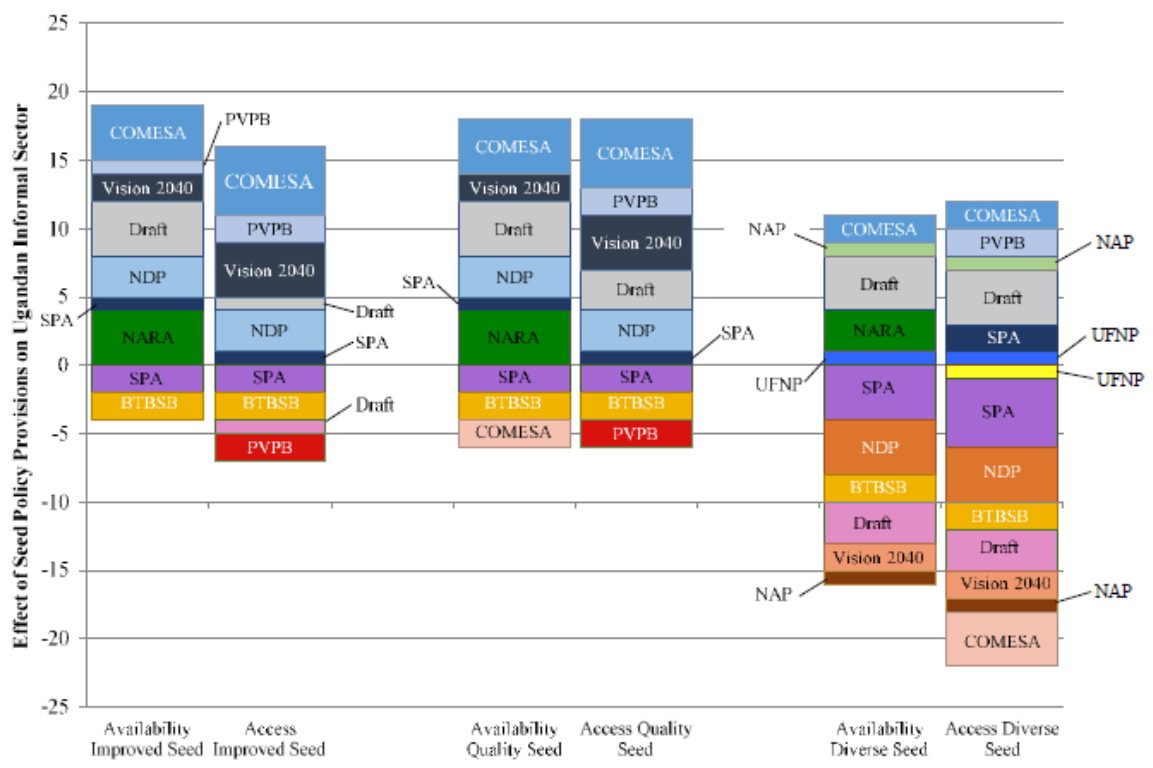

Figure 6. Uganda: net effect of seed policy provisions affecting improved, quality and genetically diverse seed in the informal sector (availability \& accessibility) 
Overall these findings - which show a strong emphasis of Ugandan policies on improved and quality-controlled seed, especially in the formal seed sector, and relatively little attention to genetically diverse landrace seed, or to informal seed system actors - are consistent with literature review findings on the effects of current seed sector policies in Uganda (Barungi et. al, 2011; Pelum, 2010; Ssebuliba, 2010).

\subsection{Potential Impacts of Draft Seed Policies}

Both Ethiopia and Uganda currently have draft seed policies that, if implemented, could result in significant changes to the current policy environment (Joughin, 2014; MAAIF, 2010; Ethiopian ATA, 2014). In Uganda, the Draft National Seed Policy (DNSP) has been under review since 2011 (MAAIF, 2010) while Ethiopia's National Seed System Development Strategy (NSSDS) was only recently formulated in early 2015. We coded provisions in both policies using the same methods as policies already implemented as described above.

Figure 7 shows the predicted effects of each major draft policy on the availability and accessibility of each seed type in the formal sector in the two countries. Overall, these policies appear to have generally positive and constructive impacts on the availability and accessibility for improved and quality-controlled seed. Only three provisions were coded as having a negative impact on the accessibility of improved seed (Uganda's Draft National Seed Policy (DNSP, 1 provision)) and on the accessibility of genetically diverse seed (Ethiopia's National Seed System Development Strategy (NSSDS, 2 provisions)). While both draft policies result in net positive impacts, Ethiopia's NSSDS would potentially have a greater positive impact on the availability and accessibility of improved and quality seeds, in part owing to substantial provisions supporting rural seed systems and farmer seed rights. These data suggest that both countries' current draft seed policies could result in a net positive score for genetically diverse seed, but at a much lower level than the expected gains for improved and quality-controlled seed. In the formal sector, each draft seed policy still primarily focuses on improved and certified quality seeds.

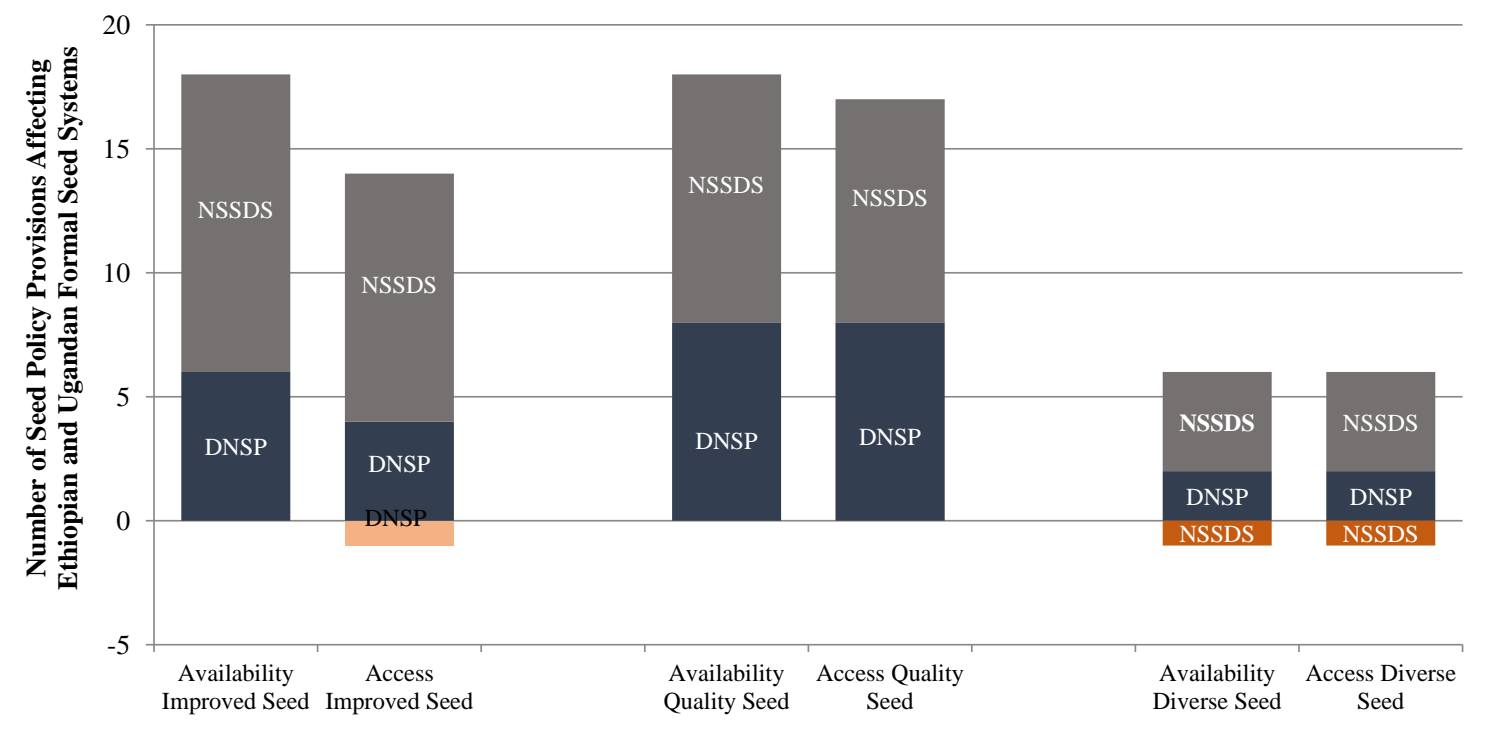

Figure 7. Potential impacts of draft national seed policies in Ethiopia and Uganda on formal seed systems

Figure 8 illustrates the potential impact that each major policy from each country could have on the availability and accessibility of each seed type in the informal sector. Ethiopia's National Seed System Development Strategy (NSSDS) scored higher than Uganda's Draft National Seed Policy (DNSP) in terms of predicted effects on availability and accessibility of improved seeds. On balance Uganda's DNSP would not improve the access to improved seeds in the informal sector (owing to some provisions enhancing access but others undermining it), while Ethiopia's NSSDS would result in a positive 5 score. The two drafts were both positive at nearly identical levels for availability and accessibility for certified quality seed. Ethiopia's NSSDS would have a markedly higher impact on the availability and accessibility of genetically diverse seed in the informal sector, scoring a net positive 9. Uganda's DNSP in contrast scores a positive 4 for both access and availability of genetically diverse landrace seed, however other provisions result in a negative 3 for both access and availability, offsetting the positive impacts. Overall, the coding suggests Ethiopia's NSSDS may have a higher positive impact on the 
accessibility and availability of improved and genetically diverse seed in the informal sector as compared to Uganda's draft seed policy.

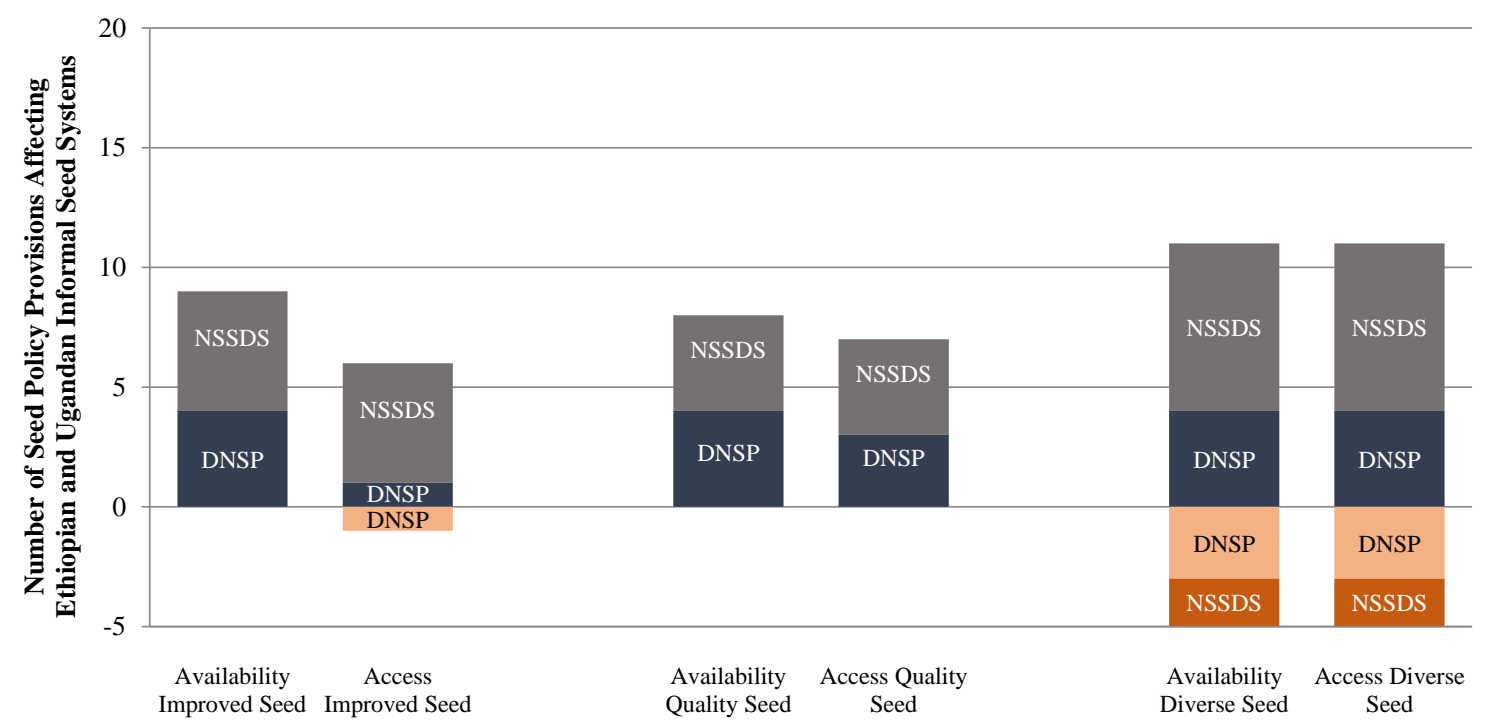

Figure 8. Potential impacts of draft national seed policies in Ethiopia and Uganda on informal seed systems

\section{Discussion}

\subsection{Seed Policy Impacts on Formal and Informal Seed Systems}

In both Ethiopia and Uganda, $80 \%$ to $90 \%$ of farmers source their seeds from informal seed systems. In Ethiopia, only $5 \%$ of land is designated to improved seed varieties (Thijssen et al., 2008), which are a key component of the formal sector. In Uganda about 13 percent of land is planted with improved seed varieties (ISSD, 2015). Despite this disparity in coverage, seed policies continue to target the formal sector. The historical disconnect between farmer participation and the amount of policies targeting the formal sector undermines the intended impacts of seed policy (McGuire \& Sperling, 2016; de Boef et al., 2010). While the formal sector may continue to be strengthened by policies and programs, the varieties, knowledge and practices of smallholders could be weakened by negligence (de Boef \& van Gastel, 2008; Engels et al., 2008). In our coding of policy provisions, while there were net positive effects of policies on both the formal and the informal sectors of both Ethiopia and Uganda, the positive effects for the informal sector were dwarfed by the overwhelming positive impacts of seed policies accruing to the formal sector (which had nearly two times as many positive effects overall). This imbalance may imply a neglect of informal seed systems in national policies - which might ultimately cause negative outcomes as the formal sector expands and the informal sector (albeit perhaps unintentionally) wanes.

Uganda and Ethiopia appear to follow similar trends in terms of favoring formal seed sector development; however, Ethiopia does have more policies relating to and affecting the informal sector than Uganda. This difference can largely be explained by the policies that exist in Ethiopia such as the National Seed Industry Policy (NSIP) of 1992, which explicitly seeks to involve the informal seed sector in agricultural development efforts, and the Access to Genetic Resources, Community Knowledge and Community Rights Proclamation (GRCKCR), which acknowledges the value of these indigenous resources and benefits of accessing them (National Seed Industry Policy, 1992; Proclamation No. 482/2006, 2006). In recognition of the role of the informal sector in realizing these policy goals, some authors have recently suggested the development of intermediate seed systems could act as a 'bridge' between the formal and informal seed sectors and help provide quality seed in the informal sector (Louwars et al., 2012). In Uganda's Draft National Seed Policy, for example, there are provisions for Quality Declared Seed (QDS) as a legally sanctioned category of seed, allowing farmers to self-certify their seed and thereby increase the availability of quality and genetically diverse seed through the informal sector.

\subsection{Effects of Seed Policies on Agro-Biodiversity in Ethiopia and Uganda}

As noted by Di Falco et al. (2010), crop biodiversity provides means for adaptability to a fluctuating environment, while also enabling stability in crop yield and supply. The in situ conservation of crop genetic 
diversity has become increasingly important in the face of climate change as well as in the wake of rapidly expanding commercial agriculture worldwide which has favored a relatively limited number of modern improved varieties. Thus, when assessing policies and their relation to agro-biodiversity, an important consideration is policies' promotion of genetic diversity, critical for climate change adaptation, short-term food security, and long-term heightened productivity (Tura et al., 2010; Engels et al., 2008).

Overall, the results of this analysis suggest that Ethiopia and Uganda's seed policies have a much larger net-positive impact on the availability and accessibility of improved seed and quality-controlled varieties (especially in the formal sector) than genetically diverse landrace seed. This suggests that agro-biodiversity (and potential for climate change adaptation) may not be as markedly high of a priority in current national policies as productivity factors such as high yield. Without efforts in conservation and general support through seed banks or other seed conservation institutions, this places genetically diverse landraces in a vulnerable position. Ethiopia does appear to have more policies that prioritize seed genetic diversity, in part attributable to the fact that for decades tools such as community seed banks have had more of a presence in Ethiopia than in Uganda. But more generally Ethiopia's policies tend to be more conservation-oriented than Uganda's - indeed, one of Uganda's earliest seed policies, the Agricultural Plant and Seeds Statute (amended by the Seeds and Plants Act (SPA)) concentrated only on "usage" - i.e., variety registration and release, certification and quality standards (Agricultural Plant and Seeds Statute, 1994). This contrasts with Ethiopia's National Seed Industry Policy (NSIP), which preceded Uganda's policy by 2 years, and had a particularly strong focus on both conservation and usage. Ethiopia's NSIP highlighted both the importance of increasing improved varieties and the tools by which the formal and informal sectors can produce and distribute these seeds, as well as the importance of genetic diversity, for which it had an entire provision detailing "Plant Genetic Resources Conservation and Development" (National Seed Industry Policy, 1992).

The promotion of quality seed in the formal sector aims to increase farmers' usage of ensured high yield and stable seed (CTA, 2014). Access and availability of quality seed is primarilyachieved through increasing a country's capacity to test, certify and label seed (MacRobert, 2008). But when tests are primarily done on the value for cultivation and use (VCU, i.e., yield) of the variety, and on its uniformity and stability, the focus of national policy efforts on improving the amount of quality seed may have unforeseen consequences on the availability and accessibility of genetically diverse seed in the informal sector. As previously noted, high on-farm agro-biodiversity increases the resilience of crops in uncertain conditions (Di Falco, 2009). Policies that only promote modern improved varieties indirectly lower the amount of genetically diverse seed available to smallholder farmers (de Boef \& Bishaw, 2008).

\subsection{Farmer Goals versus Policy Goals}

Future research should continue to carefully evaluate the impacts of seed policy on the availability of various types of seed (including improved, local and traditional varieties), at the national, community and farm levels, and should propose options to ensure that seed policies are meeting the short- and long-term needs of medium and smallholder farmers. A recent farmer survey by Bioversity International, conducted in three Ugandan districts of Nakasake, Kabale and Sheema in 2014, further highlights how current seed policies may be missing or even unintentionally undermining - opportunities for farmers to access the seed that they desire. In this household survey, farmers reported yield as one key desirable trait - yield was the most commonly cited desirable trait by a large margin, consistent with the focus of yield-focused agricultural development strategies. However, other preferred traits reported by respondents included "taste" and "cooking characteristics," which each received over $10 \%$ of first preference ratings, while traits like "adaptability" and "resistance" (which rely heavily on the crops' genetic richness), were each ranked as the most important trait by 5 to $10 \%$ of respondents. Table 3 contrasts these farmer-reported preference rankings with keyword searches of the 21 policies reviewed through this research. Yield, which was the top preference reported by farmers, appeared the most times in policies of all the revealed preferences. But taste and cooking characteristics, the number two and three ranked terms for farmer's stated preferences, did not appear once in any of the coded policies. 
Table 3. Count of Farmer Bean Trait Preferences in Policies

\begin{tabular}{lll}
\hline Farmer Preference & Term & Count in Relevant Policies \\
\hline 1 & Yield & 76 \\
2 & Taste & 0 \\
3 & Cooking Characteristics & 0 \\
4 & Adaptability or Resistance & 1 \\
5 & Nutrition & 52 \\
Related Terms & Pests & 101 \\
Related Terms & Disease & 83 \\
Related Terms & Sustainability & 87 \\
\hline
\end{tabular}

Ultimately, while most contemporary seed policies and production models target yield, farmers' desirable traits are more complex and place a greater value on diversity than is recognized by researchers and policymakers (de Boef \& Bishaw, 2008).

\section{Conclusions}

This paper provided insights into how seed and genetic resources policies may affect smallholders' access to quality seed of a wide range of genetic diversity. The methodology involved a systematic evaluation of seed and related genetic resources policies through the coding of 117 discrete policy provisions distilled from the policy documents; mainly availability or access to quality and diverse seed. Findings suggest that seed policies are largely framed and formulated to regulate and support the formal seed sector; yet the bulk of seed used by smallholders in the two countries are from the informal sector. Upon further analysis of the policies, we find that while national seed policies have some direct negative impacts on informal seed systems through introducing additional restrictions and costs on farmer- and community-based seed development and exchange, as it does in the lack of positive impacts in the informal seed sector. Although the formal seed sector is the primary source of new crop varieties, and is home to most of the capacity in scientific plant breeding, extension services and credit., the informal sector is the primary source of genetic diversity and is an important link to farmers' traditional knowledge, which forms the basis and the genetic pool for breeding for new varieties. Despite, this, the polices analyzed here show little support for informal seed systems, and relatively little support for genetic diversity (relative to seed productivity, homogeneity, health, and other indicators of "quality") in either formal or informal seed systems.

Although this study provides a good picture of the implications of contemporary seed policies in East Africa; it is limited to a coding scheme which is developed by the authors and not actual observed on-the ground impacts. Further study is needed to ascertain the true medium- and long-term impacts of these policies on seed genetic diversity, seed systems, and farmer livelihoods. Moreover, it should be recognized that the historical focus of seed policies on improved varieties and quality standards has delivered important benefits, and these goals should remain as considerable foci of policy (Tura et al., 2010; Thijssen et al., 2008). But it should also be acknowledged that despite decades of agricultural modernization approaches, many countries in Africa, including Ethiopia and Uganda, have remained plagued by food insecurity. A lack of funding behind well-intentioned policies coupled with limited enforcement and institutional capacity undoubtedly plays a role in the failure to translate the text of policies into tangible improvements in seed systems and farmer welfare (Joughin, 2014; Dorosh and Rashid, 2013; Sperling \& McGuire, 2010). But while these limitations to implementation exist, the results of this study also raise questions about whether agricultural policies currently address the causes underlying food insecurity. The findings of this study thus relate to a broader discussion on the root causes of food insecurity - and whether market-oriented outcomes such as the yield of staple crops traded through formal channels should remain the primary indicator by which agricultural development progress is measured (Jones et al., 2013). For example, an alternative metric of success - nutritional security, often mistakenly used interchangeably with food security - measures the ability of individuals and households to access well-balanced and nutritious meals (Jones et al., 2013; FAO, 2013). Further research could adapt the simple methods we have developed in this study to explore whether national agricultural policies (including seed policies) emphasize crop yield at the expense of balanced nutrition, in a manner similar to the pattern we observe of policies favoring improved seed and quality at the expense of genetic diversity and farmer-desired traits. Such research could potentially help identify gaps between policies and core issues of food insecurity (Benson, 2004).

Seed genetic diversity is one tool in the arsenal against climate change, food insecurity and poverty, as it fosters resilience and availability of food crops through improving soil quality, increasing productivity, and expanding the timeframe within which fields are productive due to varying seasonal outputs (Teklewold et al., 2010; Di 
Falco et al., 2010; Lipper et al., 2005). Integrated approaches to seed sector reform, meaning those that involve both formal (government focus) and the informal sector (smallholder focus), can be used to address food insecurity while also positively affecting seed genetic diversity for the success of smallholder farmers in East Africa (Sisay et al., 2017; Engels et al., 2008). Moreover, the development of intermediate seed systems might bridge the gap between formal and informal seed systems, improving access to quality seed in the informal sector at lower costs, ultimately improving productivity and food security. To continue to promote the conservation and use of agrobiodiversity in both Ethiopia and Uganda, there will be important roles for policies that promote genetic diversity and that strengthen both formal and informal seed systems. With more and more studies highlighting the need for integrated seed systems with a pluralistic approach, policy directions should also follow suit and create 'space' for seed systems that meet the realities of farmers.

Seed system reform is a dynamic endeavor; it must balance the need for a strong regulatory framework with the benefits of a free market seed system while also taking into consideration local/smallholder practices, needs and livelihoods. Many believe that a competitive free market seed system could provide the highest quality seeds at the lowest price (Joughin, 2014; Tripp \& Rohrbach, 2001), while others contend that without a stringent regulatory framework, quality will not be ensured (Ssebuliba, 2010). But the issue is also further complicated by the multiple channels through which seed reaches rural farmers - systems which to this date remain poorly understood and relatively unsupported by national and international policy frameworks.

\section{Acknowledgments}

Portions of the study reported in this paper were supported by the projects "Improving Seed Systems for Smallholder Farmers' Food Security", funded by the Swiss Development and Cooperation Agency; and the Genetic Resources Policy Initiative, funded by the Dutch Ministry of Foreign Affairs. T. Andrew Currier provided invaluable research assistance.

\section{References}

African Centre for Biodiversity. (2016). Changing seed and plant variety protection laws in TanzaniaImplications for farmer-managed seed systems and smallholder farms. Johannesburg, South Africa: African Centre for Biodiversity.

AGRA. (2013). The African Agriculture Status Report: Focus on Staple Crops. Nairobi, Kenya: Alliance for a Green Revolution in Africa.

Alemu, D. (2011). The political economy of Ethiopian cereal seed systems: State control, market liberalization and decentralization. IDS Bulletin, 42, 69-77. https://doi.org/10.1111/j.1759-5436.2011.00237.x

Alemu, D., \& Bishaw, Z. (2015). Commercial behaviours of smallholder farmers in wheat seed use and its implication for demand assessment in Ethiopia. Development in Practice, 25, 798-814. http://dx.doi.org/10.1080/09614524.2015.1062469

Alemu, D., Mwangi, W., Nigussie, M., \& Spielman. (2008). The maize seed system in Ethiopia: challenges and opportunities in drought prone areas. African Journal of Agricultural Research, 3, 305-314.

Alemu, G. (2008). Preface. In M.H. Thijssen, Z. Bishaw, A. Beshir and W.S. de Boef (Eds.), Farmers, seeds and varieties: supporting informal seed supply in Ethiopia. (9-10). Wageningen: Wageningen International.

Altieri, M. (1999). The ecological role of biodiversity in agroecosystems. Agriculture Ecosystems and Environment, 74, 19-31. https://doi.org/10.1016/S0167-8809(99)00028-6

Asfaw, A., Tenaye, A., \& G. Endrais. (2008). Seed relief intervention and resilience of local seed systems under stress: the case of Humbo woreda in Southern Ethiopia. In M.H. Thijssen, Z. Bishaw, A. Beshir and W.S. de Boef (Eds.), Farmers, seeds and varieties: supporting informal seed supply in Ethiopia. (109-113). Wageningen, Wageningen International.

Atilaw, A. (2010). A baseline survey on the Ethiopian seed sector. AFSTA. Retrieved on 24 September, 2015 from http://afsta.org/wp-content/uploads/documents/20STUDY.pdf.

Bangwayo-Skeete, P.F., Bezabih, M., \& Zikhali, P. (2012). Crop biodiversity, productivity and production risk: panel data micro-evidence from Ethiopia. Natural Resources Forum, 36, 263-273. https://doi.org/10.1111/1477-8947.12000

Barnett, C. et al. (2011). Country Case Studies on the PASS Value Chain Strategy/ Approach and its Impact/ Effect on Smallholder Farmer Yields in Africa: East Africa Synthesis Report. Alliance for a Green Revolution in Africa. 
Barungi, J., \& Naluwairo, R. (2014). Ensuring the sustainable availability of affordable quality seeds and planting materials in Uganda: a review of Uganda's Draft National Seed Policy. ACODE Policy Research Paper Series, 63.

Bellon, M.R., (2004). Conceptualizing interventions to support on-farm genetic resource conservation. World Development, 32, 159-172 . . https://doi.org/10.1016/j.worlddev.2003.04.007

Ben Hassen, M., Monaco, F., Facchi, A., Romani, M., Valè, G., \& Sali. G. (2017). Economic Performance of Traditional and Modern Rice Varieties under Different Water Management Systems. Sustainability, 9, 347. https://doi.org/10.3390/su9030347

Benin, S., Nin-Pratt, A., \& Randriamamonjy, J. (2007). Agricultural productivity growth and government spending in sub-Saharan Africa. Washington, DC, IFPRI

Benson, T., Spelman, D., \& L., Kasa. (2014). Direct seed marketing program in Ethiopia in 2013: an operational evaluation to guide seed sector reform. IFPRI Publications. 19, 1-46. https://doi.org/10.2139/ssrn.2483989

Bishaw, Z., Struik, P. C., van Gastel, A. J. G. (2013). Farmer's seed sources and seed quality: 2. Seed health. International Journal of Plant Production, 7, 637-657. https://doi.org/10.1080/15427528.2012.670695

Bishaw, Z., Struik, P., van Gastel, A. J. G., (2010). Wheat seed system in Ethiopia: farmers' varietal perception, seed sources, and seed management. Journal of New Seeds, 11, 281-327. http://dx.doi.org/10.1080/1522886X.2010.518302

Bishaw, Z., Struik, P., van Gastel, A. J. G., (2012). Farmers' seed sources and seed quality: 1. Physical and physiological quality. Journal of Crop Improvement, 26, 655-692. http://dx.doi.org/10.1080/15427528.2012.670695

Bocci, R. et al. (2010). Farm Seed Opportunities: Opportunities for Farm Seed Conservation, Breeding and Production.

Ceccarelli, S. (1996). Positive interpretation of genotype by environment interactions in relation to sustainability and biodiversity. In M.Cooper, and G. L.Hammer (Eds.), Plant Adaptation and Crop Improvement. (467-486). Wallingford, UK: CABI Publishing.

Coomes, O. T., McGuire, S. J., Garine, E., Caillon, S., McKey, D., Demeulenaere, E., \& Emperaire, L. (2015). Farmer seed networks make a limited contribution to agriculture? Four common misconceptions. Food Policy, 56, 41-50. https://doi.org/10.1016/j.foodpol.2015.07.008

Coulibaly, H., Bazile, D., \& Sidibé, A., (2014). Modelling seed system networks in Mali to improve farmers seed supply. Sustainable Agriculture Research, 3, 18-32. https://doi.org/10.5539/sar.v3n4p18

Croft, M. M., Marshall, M. I., Odendo, M., Ndinya, C. et al. (2016). Formal and informal seed systems in Kenya: supporting indigenous vegetable seed quality. The Journal of Development Studies, 1-18. https://doi.org/10.1080/00220388.2017.1308487

CTA. (2014). Seed systems, science, and policy in East and Central Africa. The Technical Centre for Agricultural and Rural Cooperation. Retrieved 4 October, 2015 from: http://www.cta.int/images/1832_PDF.pdf.

de Beof, W., \& Bishaw, W. (2008). A system perspective for linking farmers and professionals supporting farmers practices in seed supply. In M.H. Thijssen, Z. Bishaw, A. Beshir and W.S. de Boef (Eds.), Farmers, seeds and varieties: supporting informal seed supply in Ethiopia. (47-54). Wageningen, Wageningen International.

de Boef, W. \& van Gastel, A. (2008). Opportunities for policy development supporting informal seed supply of local crops and varieties in Ethiopia. In M.H. Thijssen, Z. Bishaw, A. Beshir and W.S. de Boef (Eds.), Farmers, seeds and varieties: supporting informal seed supply in Ethiopia. (332-336). Wageningen, Wageningen International.

de Boef, W. S., Dempewolf, H., Byakweli, J. M., \& Engels, J. M. M. (2010). Integrating genetic resource conservation and sustainable development into strategies to increase the robustness of seed systems. Journal of Sustainable Agriculture, 34, 504-531. https://doi.org/10.1080/10440046.2010.484689

de Jonge, B. (2014). Plant Variety Protection in Sub-Saharan Africa: Balancing Commercial and Smallholder Farmers' Interests. Journal of Politics and Law, 7, 100. https://doi.org/10.5539/jpl.v7n3p100

Di Falco, S., Bezabih, M., \& Yesuf, M. (2010). Seeds for livelihood: crop biodiversity and food production in Ethiopia. Ecological Economics, 69, 1695-1702. https://doi.org/10.1016/j.ecolecon.2010.03.024 
Dorosh, P. A., \& Rashid, S. (Eds.). (2013). Food and agriculture in Ethiopia: Progress and policy challenges. Food and Agriculture in Ethiopia: Progress and Policy Challenges. University of Pennsylvania Press.

Engels, J., Vianney, J., Dempewolf, H., \& de Boef, W. (2008). Robust seed systems: integrating a genetic resource conservation and sustainable livelihood perspective in strategies supporting informal seed supply. In M.H. Thijssen, Z. Bishaw, A. Beshir and W.S. de Boef (Eds.), Farmers, seeds and varieties: supporting informal seed supply in Ethiopia. (73-86). Wageningen, Wageningen International.

Ethiopian ATA \& Ethiopian Ministry of Agriculture. (2015). Seed System Development Strategy.

Ethiopian ATA. (2015). About: Origin of the Agency. Ethiopian Agricultural Transformation Agency

Evenson, RE, Gollin, D (Eds.) (2002). Crop Variety Improvement and its Effect on Productivity: The Impact of International Agricultural Research. Wallingford, U.K: Cabi Publishing.

FAO. (2013). Draft Guide for National Seed Policy Formulation, Rome, IT: Food and Agriculture Organization of the United States

Fosu, A. K. (1992). Political instability and economic growth: evidence from Sub-Saharan Africa. Economic Development and Cultural Change, 40, 829-841. https://doi.org/10.1086/451979

Gebeyehu G., Dabi, G., \& Shaka, G. (2001). Focus on seed programs: the Ethiopian seed. International Center for Agricultural Research in Dry Areas (ICARDA).

Gibson, R. (2013). How sweet potato varieties are distributed in Uganda: actors, constraints and opportunities. Food Security, 5, 781-791. https://doi.org/10.1007/s12571-013-0302-8

Global Food Security Index. (2015). The Economist Intelligence Unit.

Holden, S., \& Shiferaw, B. (2004). Land degradation, drought and food security in a less-favoured area in the Ethiopian highlands: a bio-economic model with market imperfections. Agricultural Economics, 30, 31-49. https://doi.org/10.1016/j.agecon.2002.09.001

ISSD Africa. (2012). ISSD Briefing Note-September 2012: Ethiopia Seed Sector Assessment. ISSD Briefing Note.

Jarvis, D. I., Hodgkin, T., Brown, A. H. D., Tuxill, J., López Noriega, I., Smale, M., \& Sthapit, B. (2016). Crop genetic diversity in the field and on the farm. New Haven: Yale.

Jones, A. D., Ngure, F. M., Pelto, G., \& Young, S. L. (2013). What are we assessing when we measure food security? A compendium and review of current metrics. Advances in Nutrition: An International Review Journal, 4, 481-505. https://doi.org/10.3945/an.113.004119

Joughin, J. (2014). The political economy of seed reform in Uganda : promoting a regional seed trade market. Africa Trade Practice Working Paper Series, 3.

Kaguongo, W., Kyotalimye, M., Waithaka, M., Ronoh, M., \& Ng'ang'a, N. (2014). Enhancing adoption of harmonised seed standards, regulations and procedures in Eastern and Central Africa. In Judith A. Francis (Eds.). Seed Systems, Science and Policy in East Africa, report prepared for The Technical Centre for Agricultural and Rural Cooperation.

Kahane, R., Hodgkin, T., Jaenicke, H., Hoogendoorn, C., Hermann, M., Keatinge, J. D. H., Hughes, J., Padulosi, S., \& Looney Norman. (2013). Agrobiodiversity for food security, health and income. Agronomic Sustainable Development, 33. 671-693. https://doi.org/10.1007/s13593-013-0147-8

Katungi, E., Farrow, A., Mutuoki, T., Gebeyehu, S., Karanja, D., Alemayehu, F., \& Buruchara, R. (2010). Improving common bean productivity: an analysis of socioeconomic factors in Ethiopia and Eastern Kenya. Baseline Report Tropical Legumes II. Centro Internacional de Agricultura Tropical-CIAT. Cali, Colombia.

Keyser, J. (2012). Africa trade policy notes. World Bank, 33, 1-12.

Lipper, L., Anderson, C. L., \& Dalton, T. J. (2010). Seed trade in rural markets: implications for crop diversity and agricultural development. London, UK: Earthscan.

Lipper, L., Cavatassi, R., \& Winters, P. C. (2005). Seed systems, household welfare and crop genetic diversity: an economic methodology applied in Ethiopia. UN FAO Agricultural and Development Economics Division. ESA Technical Paper.

Louwaars, N. P. (2007). Seeds of Confusion: The impact of policies on seed systems. Wageningen University Research 
Louwaars, N. P., \& De Boef, W. S. (2012). Integrated seed sector development in Africa: a conceptual framework for creating coherence between practices, programs, and policies. Journal of Crop Improvement, 26, 39-59. https://doi.org/10.1080/15427528.2011.611277

Louwaars, N. P., de Boef, W. S., \& Edeme, J. (2013). Integrated seed sector development in Africa: a basis for seed policy and law. Journal of Crop Improvement, 27, 186-214. https://doi.org/10.1080/15427528.2012.751472

MAAIF. (2010). Agriculture Sector Development Strategy and Investment Plan: 2010/11-2014/15. Kampala: Ministry of Agriculture, Animal Industry and Fisheries.

MacRobert, J. (2008). Small-scale and community enterprises: increasing local availability of seed and enhancing farmers' access to it: Supporting the development of small to medium-scale seed enterprises in sub-Saharan Africa. In M.H. Thijssen, Z. Bishaw, A. Beshir and W.S. de Boef (Eds.), Farmers, seeds and varieties: supporting informal seed supply in Ethiopia. (225-231). Wageningen, Wageningen International.

Mahop, M. T. (2015). African seed laws and policies: an exploration of the space for farmers' seed systems in Africa. Pilot Phase for a comprehensive programme on integrated seed sector development in Africa, Nairobi.

McGuire, S., \& Sperling, L. (2016). Seed systems smallholder farmers use. Food Security, 8, 179-195. https://doi.org/10.1007/s12571-015-0528-8

Medhin, S., \& Gebeyehu, L. (2000). Farmer-based seed production and marketing scheme in Ethiopia: experiences and future prospects. In S. Kugbei, M. Turner and P. Witthaut (Eds.). Finance and Management of Small-scale Seed Enterprises (112-121). Aleppo: ICARDA.

Mugomba, Agrippah, T. (1978). Regional organisations and African underdevelopment: the collapse of the East African community. The Journal of Modern African Studies, 16, 261-272. https://doi.org/10.1017/s0022278x00021716

Munyi, P., \& de Jonge, B. (2015). Seed system support in Kenya: Consideration for an integrated seed sector development approach. Journal of Sustainable Development, 8, 161-173. http://dx.doi.org/10.5539/jsd.v8n2p161

Ngos, T. (2012). ISSD Briefing Note - September 2012 Uganda Seed Sector Assessment, (September), 1-7.

Obong, Y., Omony, T., Rachkara, P., \& Gibson, R. W. (2017). Disseminating modern sweetpotato varieties using participatory variety demonstration trials on informal nodal multipliers' fields at hub locations. Journal of Crop Improvement, 31, 229-246. http://dx.doi.org/10.1080/15427528.2017.1282910

Pautasso, M., Aistara, G., Barnaud, A. et al. (2013). Seed exchange networks for agrobiodiversity conservation: A review. Agronomy for Sustainable Development, 33, 151-175. http://doi.org/10.1007/s13593-012-0089-6

PELUM-Uganda. (2012). Is the future of the small scale farmer bleak or bright? The Seed Sector of Uganda.

PELUM-Uganda. (2014). Building farmer led seed systems. The Seed Sector of Uganda.

People's Democratic Republic of Ethiopia (2010). Agricultural Sector Policy and Investment Framework.

People's Democratic Republic of Ethiopia. (1971). Plant Protection Decree.

People's Democratic Republic of Ethiopia. (1992). National Seed Industry Policy.

People's Democratic Republic of Ethiopia. (1992). Plant Quarantine Council of Ministers Regulation.

People's Democratic Republic of Ethiopia. (1993). Proclamation No. 56/1993.

People's Democratic Republic of Ethiopia. (1993). Proclamation No. 122/1998. National Seed Industry Agency.

People's Democratic Republic of Ethiopia. (1998). Institute of Biodiversity Conservation and Research, Establishment Proclamation of 1998.

People's Democratic Republic of Ethiopia. (2000). National Seed Proclamation of 2000.

People's Democratic Republic of Ethiopia. (2004). Proclamation No.381/2004: Institute of Biodiversity Conservation and Research Establishment

People's Democratic Republic of Ethiopia. (2006). Proclamation No. 481/2006: Plant Breeder's Right Proclamation.

People's Democratic Republic of Ethiopia. (2006). Proclamation No. 482/2006: Access to Genetic Resources 
and Community Knowledge and Community Rights Proclamation.

People's Democratic Republic of Ethiopia. (2013). National Seed Proclamation of 2013.

Rachkara, P., Phillips, D. P., Kalule, S. W., \& Gibson, R. W. (2017). Innovative and beneficial informal sweetpotato private enterprise in northern Uganda. Food Security, 9, 595-610. http://doi.org/10.1007/s12571-017-0680-4

Reardon, T., \& Timmer, C. P. (2012). The economics of the food system revolution. Annual Review of Resource Economics, 4, 225-264. https://doi.org/10.1146/annurev.resource.050708.144147

Reimer, J., \& Fisher, M. (2016). Are modern varieties always better? An economic analysis of maize varietal selection. African Journal of Agricultural and Resource Economics, 9, 270-285.

Republic of Uganda (2006). Seeds and Plant Act, 2006.

Republic of Uganda (2013). National Agriculture Policy.

Republic of Uganda (2014). The Plant Variety Protection Act.

Republic of Uganda (2015). Plant Protection and Health Act.

Reynolds, T., \& Otieno, G. (2015). Accessing seed and genetic diversity: the micro-level dynamics of farmer's choices, knowledge and exchange of genetic resources and its implications for policy. Bioversity International.

Saha, S., Jenkins, J. N., \& McCarty Jr, J. C. (2001). A novel strategy for general sustainability and resistance management in pest and pathogen resistant crops. Journal of New Seeds, 2, 53-61. https://doi.org/10.1300/j153v02n03_04

Santos, B. (2007). Seed Quality and Seeding Technology. University of Florida: IFAS Extension.

Seatini. (2010). Uganda's Plant Variety Protection Bill, 2010: where are the farmer and community rights? 1-14.

Singh, R. P., Kumar, A., \& Pal, S. K. (2016). The prevalence, productivity and protection of traditional varieties vis-à-vis modern varieties in Eastern India: An appraisal. Jharkhand Journal of Development and Management Studies, 14, 6955-5970. https://doi.org/10.5958/0973-9343.2016.00004.1.

Sisay, D. T., Verhees, F. J., \& van Trijp, H. C. (2017). Seed producer cooperatives in the Ethiopian seed sector and their role in seed supply improvement: A review. Journal of Crop Improvement, 31(3), 323-355. https://doi.org/10.1080/15427528.2017.1303800

Smale, M. (Ed.) (2005). Valuing Crop Biodiversity: On-Farm Genetic Resources and Economic Change. Wallingford, UK: CABI Publishing. https://doi.org/10.1079/9780851990835.0000

Sperling, B. L., \& McGuire, S. (2010). Understanding and strengthening informal seed systems. Experimental Agriculture, 46, 119-136. https://doi.org/10.1017/s0014479709991074

Sperling, L., Deressa, A., \& Assefa, S. (2007). Long-term seed aid in Ethiopia: past, present, and future perspectives. International Development Research Centre, 1-145.

Sperling, L., Deressa, A., Assefa, S., Assefa, T., \& Mcguire, S. (Eds.) (2007). Long-Term Seed Aid in Ethiopia: Past, Present, and Future Perspectives. United Kingdom: The Overseas Development Group \& The School of Development Studies, University of East Anglia.

Sperling, L., Osborn, T., \& Cooper, D. (Eds.) (2004). Towards effective and sustainable seed relief activities: FAO Plant Protection and Production Paper. Rome: Food and Agriculture Organization of the United Nations, Rome.

Sperling, L., Osborn, T., \& Cooper, H. (2004). Towards effective and sustainable seed relief activities: report of the workshop on effective and sustainable seed relief activities. Food and Agriculture Organization of the United Nations, Rome.

Spielman, D. J., \& Kennedy, A. (2016). Towards better metrics and policymaking for seed system development: Insights from Asia's seed industry. Agricultural Systems, 147, 111-122. https://doi.org/10.1016/j.agsy.2016.05.015

Spielman, D., Kelemwork, D., \& Alemu, D. (2011). Seed, fertilizer and agricultural extension in Ethiopia. International Food Policy Research Institute.

Ssebuliba, R. N. (2010). Baseline Survey of the Seed Sector in Uganda, In Relation to Regional Harmonization of Seed Legislation. African Seed Trade Association (AFSTA). 
Tadesse, Y., Almekinders, C. J., Schulte, R. P., \& Struik, P. C. (2016). Tracing the seed: Seed diffusion of improved potato varieties through farmers' networks in Chencha, Ethiopia. Experimental Agriculture, 1-16. https://doi.org/10.1017/S001447971600051X

TASAI. (2015). Uganda policy brief, 1-6. The African Seed Index (TASAI). Uganda Policy Brief.

Teklewold, H., Kassie, M., Shiferaw, B., \& Köhlin, G. (2013).Cropping system diversification, conservation tillage and modern seed adoption in Ethiopia: Impacts on household income, agrochemical use and demand for labor. Ecological Economies, 93. 85-93. https://doi.org/10.1016/j.ecolecon.2013.05.002

Thijssen, M. H., Bishaw, Z., Beshir, A., \& de Boef, W. S. (Eds). (2008). Farmers, seeds and varieties: supporting informal seed supply in Ethiopia. Wageningen: Wageningen International.

Thijssen, M.H., Borman, G., Verhoosel, K., Mastenbroek, A., \& Heemskerk, W. (2015). Local seed businesses in the context of Integrated Seed Sector Development. Community Seed Production, 39-45.

Tripp, R., \& Louwaars, N. (1997). Seed regulation: choices on the road to reform. Food Policy, 22, 433-446. https://doi.org/10.1016/s0306-9192(97)00033-x

Tripp, R., \& Rohrbach, D. (2001). Policies for African seed enterprise development. Food Policy, 26, 147-161. https://doi.org/10.1016/s0306-9192(00)00042-7

Tura, M., Aredo, D., Tsegaye, W., La Rovere, R., Tesfahun, G., Mwangi, W., \& Mwabu, G. (2010). Adoption and continued use of improved maize seeds: case study of Central Ethiopia. African Journal of Agricultural Research, 5, 2350-2358.

Vernooy, R. (2017). Options for national governments to support smallholder farmer seed systems: The cases of Kenya, Tanzania, and Uganda. The Hague (Netherlands): Hivos.

Vigoroux, Y., Mariac, C., De Mita, S., Pham, J.L., Gérard, B., Kapran, I., \& Sagnard, F. (2011). Selection for earlier flowering crop associated with climate variations in the Sahel. PloS ONE, 6, e19563. https://doi.org/10.1371/journal.pone.0019563

World Bank Group (2015). Enabling the Business of Agriculture 2015: Progress Report. Strengthening the Seed System. The World Bank.

\section{Copyrights}

Copyright for this article is retained by the author(s), with first publication rights granted to the journal.

This is an open-access article distributed under the terms and conditions of the Creative Commons Attribution license (http://creativecommons.org/licenses/by/3.0/). 